\title{
Medical History Yes No Indicator
}

National Cancer Institute

\section{Source}

National Cancer Institute. Medical History Yes No Indicator. NCI Thesaurus. Code C85522.

An indication of whether a medical history has been taken. 